\title{
A new Navicula (Bacillariophyta) species from low-elevation carbonate springs affected by anthropogenic disturbance
}

\author{
Marco Cantonati*1 ${ }^{*}$ Nicola Angeli ${ }^{1}$, Daniel Spitale ${ }^{1} \&$ Horst Lange-Bertalot $^{2}$
}

\author{
${ }^{I}$ Museo delle Scienze - MUSE, Limnology and Phycology Section, Corso del Lavoro e della Scienza 3, Trento, \\ Italy; *Corresponding author e-mail: marco.cantonati@muse.it \\ ${ }^{2}$ University of Frankfurt, Biologicum, Institute for Ecology, Evolution, Diversity, Max-von-Laue Straße 13, \\ Germany
}

\begin{abstract}
Diatom assemblages in carbonate spring habitats at low elevations, with low discharge, and affected by direct human impacts were studied only recently and in some geographic areas. We describe and characterize the ecology of a new Navicula species from springs with these characteristics within the basin of the River Adige in the south-eastern Alps and Alpine foothills (Province of Verona, Italy). Navicula veronensis sp. nov. is in the group of species around $N$. cincta but has distinct outline, size, central area, and proximal raphe endings. The availability of data on the distribution of the new species in streams of the Island of Cyprus allowed to quantitatively compare the ecological preferences, niche position, and niche breadth of Navicula veronensis $\mathrm{sp}$. nov. with those of allied species. The new species was found to be characteristic of medium-high conductivity freshwaters, rich in sulphates and chloride, often nitrate enriched and affected by marked discharge fluctuations and seasonal desiccation. Niche position however differed only slightly from those of morphologically-similar species, with the exception of Navicula dealpina that was found to be characteristic of oligotrophic, calciumbicarbonate rich environments with medium(-low) conductivity. Canonical Correspondence Analysis clearly showed that the most influential environmental variables determining the diatom assemblages of low-elevation carbonate springs affected by anthropogenic disturbance were nitrate enrichment, spring morphology alteration (in particular for water abstraction), and low discharge.
\end{abstract}

Key words: diatoms, Navicula veronensis sp. nov., springs, nitrates, morphology

\section{INTRODUCTION}

The genus Navicula is often one of the most speciesrich genera in spring habitats (WeRUM \& LANGE-BeRTALOT 2004; ŻELAZNA-WieCZOREK 2011; CANTONATI et al. 2012a; WoJTAL 2013). In springs high in nitrate and phosphorus it was even found to be the most species rich genus (ŻelazNa-WieCZOREK 2011). The group of species around Navicula cincta (EHRENBERG) RALFS is reported to be rare in springs (WERUM \& LANGE-BERTALot 2004; Cantonati et al. 2012a; Wojtal 2013). However, as many as three new species belonging to this species group were described from springs in recent years (ŻelaZna-WieczoreK 2011; Reichardt 2012; BEAUGER et al. 2015).

Springs are heavily exploited to gain drinking water but they are also habitats with special features (CAntonati et al. 2012b). However, low-elevation carbonate springs in densely populated areas, directly affected by various types of impacts, have been less considered than near-natural mountain springs. Some information on this type of springs is nevertheless available from Poland (WoJTAL 2013; ŻELAZnA-WIECZOREK 2011; WoJTAL \& SOBCZYK 2012), Switzerland (TAXböck \& Preisig 2007), France (Bertrand et al. 1999), and Spain (AboAl et al. 1998; Delgado et al. 2007, Maiorca). Small springs on carbonate substratum fed by local aquifers are often affected by marked discharge fluctuations and even are intermittent or seasonal. This discharge variability is likely to be enhanced by climate change in many geographic areas (CANTONATI \& LANGe-BerTalot 2009).

The characteristics of spring habitats vary markedly according to spring types (e.g., SPITALE et al. 2012). Among the most peculiar types of ambient springs are petrifying springs or Limestone Precipitating Springs (LPS) (CANTONATI et al. 2016). In spite of being the sole widely-distributed spring type included in the European Union Habitat Directive (EU-HD 1992), LPS are affected by many impacts, the most important ones being water diversion, and inadequate management due to lack of appreciation. The charac- 
teristics of diatom assemblages of petrifying springs affected by nitrate enrichment were recently discussed by DenYs \& OOSTERLYNCK (2015).

Building on the availability of a dataset on diatom assemblages in low-elevation carbonate springs affected by anthropogenic disturbance (ANGELI et al. 2010), the main objectives of this study were as follows: (1) to describe and characterize a new Navicula species; (2) to statistically assess the ecological preferences and niche of the new species; (3) to compare the optima of the new species for the main environmental factors with those of allied species; (4) to identify the most influential environmental variables determining the diatom assemblages of low-elevation carbonate springs affected by anthropogenic disturbance, providing iconography for the most frequent and abundant species.

\section{Methods}

Dataset, study area, sampling. We studied 25 springs (named "CESSPA springs" in ANGEL et al. 2010) considering two main substrata: bryophytes and lithic materials. The springs were located within the basin of the River Adige in the Provinces of Verona, Trento, and Vicenza (south-eastern Alps and Alpine foothills in the Veneto Region + Autonomous Province of Trento, Italy), and distributed along an altitudinal gradient from 62 to $1266 \mathrm{~m}$ a.s.l. The Natural History Museum of Verona provided all samples. All details on the study area, sampling, field measurements (including the compound human-disturbances' index), and hydrochemical analyses are available in ANGELI et al. (2010).

With regard to diatom sampling methods and the measurement of the main environmental parameters, CRENODAT methods were followed (CANTONATI et al. 2012a). Separate samples of all substrata considered for the analysis of diatom assemblages were taken. Epilithic diatoms were collected by brushing seven to ten cobbles or small boulders. For the epibryon, entire plantlets of the dominant bryophyte species (submerged or closest to the water) were collected, and identified to species level. The most common speci- es was Cratoneuron filicinum (Hedw.) Spruce found in 9 springs (for a complete list see ANGELI et al. 2010).

Diatom preparation, identification, and counting. The diatom samples were treated with hydrogen peroxide and hydrochloric acid, and the valves thus freed from organic substance were mounted with Naphrax ${ }^{\circledR}$ (Brunel Microscopes Ltd., Chippenham, Wiltshire, UK). For each sample three cover slips were prepared and mounted on a glass slide, and a total of 450-500 valve were counted to determine relative abundances. All slides were examined for a fixed time (3 hours) to try to find rare taxa with low relative abundance. The determination and nomenclature followed mainly KRAMMer \& Lange-Bertalot (1986-1991), Round et al. (1990), Lange-Bertalot (2001), Krammer (1997a,b, 2002-2003), Krammer \& Lange-Bertalot (2004), Reichardt (1997), Werum \& Lange-Bertalot (2004), Levkov (2009), HofMANN et al. (2011), Liu et al. (2012), Lowe et al. (2014), and JÜTTNER et al. (2015). Observations were performed with an optical microscope Zeiss Axioskop 2 equipped with phase contrast and a digital camera Axiocam (Carl Zeiss JSC, Milan, Italy). SEM observations on gold coated prepared material were made primarily at the University of Frankfurt using a Hitachi S-4500 (Hitachi Ltd., Tokyo, Japan). Further SEM observations were done at the Museo delle Scienze MUSE in Trento using a LEO XVP (Carl Zeiss SMT Ltd., Cambridge, UK) at high vacuum. All of the observations and micrography referred to in the present note were done on epilithon samples.

All samples (original samples, suspensions of prepared material, and permanent mounts) have been catalogued and deposited in the collections of the Museo delle Scienze - MUSE (Trento) (access codes: cLIM007 DIAT 637-683) along with information about the abundance of the species found and the main environmental variables.

Data processing and statistical analysis. All the statistical analyses were performed within the R statistical environment (R Core Team 2015). The optima and tolerance of species along the gradients were calculated assuming a Gaussian response curve with the package "analogue". Niche position and niche breadth were calculated using the OMI (Outlying Mean Index) analysis (DoLÉDEC et al. 2000) implemented in the "ade4" package. This method measures the marginality of species habitat distribution, i.e., the distance between the
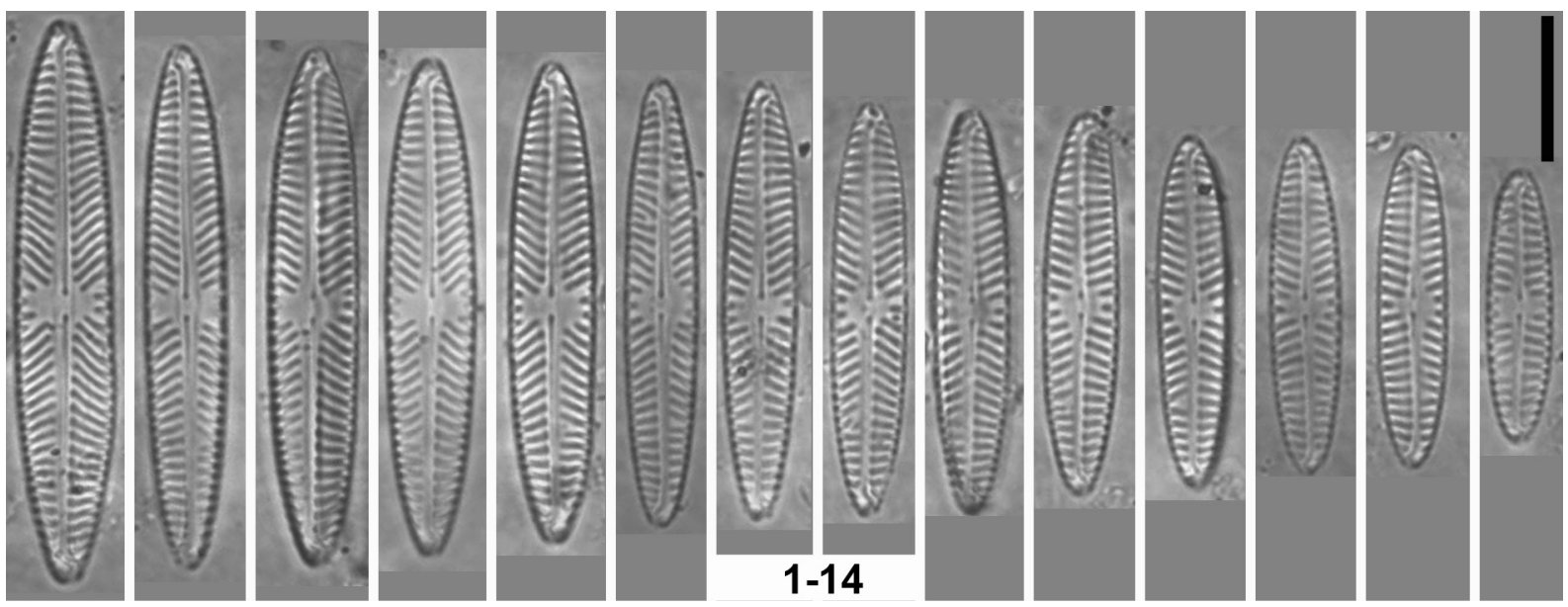

Figs 1-14. LM micrographs showing a size diminution series for Navicula veronensis sp. nov. Scale bar $10 \mu \mathrm{m}$. 
mean habitat conditions used by a species and the mean habitat conditions across the study area. Species that have high values of OMI have marginal niches (high niche position, since they occur in atypical habitats in a region), and those that have low values have non-marginal niches (low niche position, because they occur in typical habitats in a region). Tolerance index, or niche breadth, was defined as the variance term that measures the amplitude of the distribution of each species along the sampled environmental gradients. Species that have a wide niche breadth occur across a wide range of environmental conditions, and those that have low values occur only across a limited range of conditions.

The ecological preferences and niche of the new species were compared with those of morphologically similar species. To gain sufficient data on these species the following datasets had to be considered: CESSPA (ANGELI et al. 2010), CRENODAT (CANTONATI et al. 2012a), Cyprus_diatoms (CANTONATI et al. 2015).

Canonical Correspondence Analysis (CCA) of the CESSPA springs diatom assemblages was calculated with the package "vegan" without prior transformation. CCA was selected over other ordination techniques, such as redundancy analysis (RDA), after evaluation of the length of the gradient. Model selection was performed with the "orddistep" function of "vegan", an automatic stepwise model building for constrained ordination method. Only the significant environmental variables were used for the final CCA model. Significance of the CCA model, terms, and constrained axes was tested with an ANOVA like permutation test (999 permutations). In the output biplots species were labelled using OMNIDIA (LECOINTE et al. 1993) codes (new codes had to be generated for species not present in the OMNIDIA codes' list).

\section{Results}

Navicula veronensis LANGe-Bertalot et CANTONATI sp. nov. (Figs 1-14, 15-17)

Description (compared to Navicula cincta (EHRENBERG) RALFs; SEM outside view shown in Fig. 18 for comparison)

Light microscopy (Figs 1-14): Valves linear-lanceolate, becoming linear-elliptical-lanceolate to elliptical at the end of the size diminution cycle (smallest cell cycle stages). Ends becoming gradually wedge-shaped, finally obtusely rounded. Length $18.8-40 \mu \mathrm{m}$, width 4.2-6.6 $\mu \mathrm{m}$. Length-to-width ratio $=4.2-6.0$ (not 2.5-5.3). Raphe filiform, rather straight, with slightly expanded central pores that appear not noticeably deflected to the primary or secondary side of the valve; terminal fissures like a question mark. Axial area rather narrow, only very slightly expanded proximally. Central area broadly rectangular or transapically elliptical or bow-tie-shaped in large specimens, somewhat variable and less broad in smaller ones; 2-4 striae are distinctly shortened on either side (in comparison, the central area of Navicula cincta is distinctly smaller, the central striae are less and irregularly shortened). The other striae are rather strongly radiate in proximal parts, becoming abruptly convergent at the Voigt discordan- ce; remarkable is the consistent number of 11-13 in 10 $\mu \mathrm{m}$ (not more variable, between 8-12 comparatively). Lineolae are not resolvable under the LM.

Scanning electron microscopy (Figs 15-17: Figs 1516 external views, Fig. 17 internal view): Areolae (lineolae) c. 50 (not 40 or less) in $10 \mu \mathrm{m}$.

Holotype (designated here): Torricelle spring epilithon (slide) deposited in the collections of the Museo delle Scienze - MUSE in Trento (Italy), accession code: cLIM007 DIAT 680. Since the amount of material in the epilithon sample was small, epibryon from the same spring is available as supplementary (paratype) material (suspension of prepared material + original fixed sample).

Isotypes: Diatom collection Botanischer Garten und Botanisches Museum Berlin-Dahlem, Freie Universität Berlin (Berlin, Germany), Codes: B 400041529 (slide), B 400041530 (cleaned material), B 400041531 (row material, bryophytes, paratype); and ANSP Diatom Herbarium (The Academy of Natural Sciences of Drexel University, Philadelphia, PA, USA), Codes: ANSP GC 14460 (isotype slide), ANSP GCM 15145 (cleaned material), ANSP GCM 15146 (raw paratype material).

Iconotype: Fig. 11

Type locality: Torricelle (longitude: 11.004323, latitude: 45.469326, WGS84 system) is a partially-tapped spring within the urban area of Verona at an elevation of $220 \mathrm{~m}$ a.s.l. The spring discharges out of a tunnel in which boulders and cobbles are partly stabilized with concrete. The spring head receives light through heavy metal gratings. The species was found to occur both on lithic material and on bryophytes [Eurhynchium pulchellum var. pulchellum (HEDw.) JENN.].

Etymology: The name refers to the geographic location of the type locality, a spring in the urban area of the town of Verona in northern Italy.

Taxonomic comments: Other more or less resembling European taxa (Table 1) are Navicula cariocincta LANGE-Bertalot in TSARENKo et al. (2000) and $\mathrm{Na}$ vicula dealpina LANGE-Bertalot 1993, the latter one being significantly broader, $8-12 \mu \mathrm{m}$. Both are mainly distinguished by much coarser lineolae that are easy to resolve with the LM, c. 30 or c. 26 in $10 \mu \mathrm{m}$ respectively. Also Navicula cari EHRENBERG possesses a similar complex of characters but differs by less densely spaced lineolae, 32-40 in $10 \mu \mathrm{m}$. Navicula seibigiana LANGE-BERTALOT has a different outline and lower stria and lineola density. Navicula wiesneri LANGE-BERTALOT has a different outline (in particular the obtuselyrounded ends), and a lower lineola density.

Ecological preferences and niche of Navicula veronensis sp. nov.

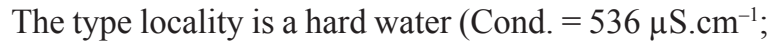
$\mathrm{pH}=8.0$ ) ambient spring with low discharge (about 0.5 
$\left.1 . \mathrm{s}^{-1}\right)$, high nitrate content $\left(25 \mathrm{mg} \cdot \mathrm{l}^{-1}\right)$, relatively high chlorides concentrations $\left(11.7 \mathrm{mg} . \mathrm{l}^{-1}\right)$, and relativelyhigh temperature $\left(12^{\circ} \mathrm{C}\right) . N$. veronensis was observed also on stones at 10 stream monitoring stations on the Island of Cyprus (CANTONATI et al. 2015), always with very low abundances (usually $<0.2 \%$ and only once with $0.9 \%)$. These streams are both perennial $(\mathrm{N}=6)$ and intermittent $(\mathrm{N}=4)$, have low discharge $(15-190$ $\left.1 . \mathrm{s}^{-1}\right)$, alkaline $\mathrm{pH}(7.9-8.3,8.9)$, high conductivity (465-683, $2850 \mu \mathrm{S} . \mathrm{cm}^{-1}$ ), relatively-high temperature $\left(8.4-18.3^{\circ} \mathrm{C}\right)$, mostly high nitrate $(1.5-20.4 \mathrm{mg}$ $\mathrm{L}^{-1}$ ) but mostly low total phosphorus $\left(3-34 \mu \mathrm{g} .1^{-1}\right)$, high sulphate $\left(36-56,118 \mathrm{mg} .1^{-1}\right)$ and chloride (34-53 mg. $\left.1^{-1}\right)$. At the type locality the species was found more abundantly on lithic material (1.2\% relative abundance) than on mosses $(0.4 \%)$.

The ecology of $N$. veronensis was not clearly differentiated when compared to other morphologically similar species, $N$. cincta, $N$. cariocincta, $N$. cari, and $N$. dealpina (Table 2). All the species, with the exception of $N$. dealpina, occurred in quite similar habitats (Figs 19-24 boxplots). The analyses of niche parameters revealed that $N$. veronensis sp. nov. has a wider ecological tolerance compared to other similar species. The ecological niches of these species were largely overlapped with the exception of $N$. dealpina, which showed low optima for most of the environmental factors. $N$. dealpina was the sole species of the group with a quite distinct niche (Figs 25-30).

\section{Diatom assemblage composition and main environ- mental determinants}

Overall, 24 samples of bryophytes, 21 of brushed lithic material, and 2 of macroalgae were examined. The analysis of diatoms (all substrata) of the springs studied allowed the identification of 139 taxa belonging to 40 genera (Supplementary Table S1). The 30 comparatively most abundant species are shown in Supplementary Fig. S1.

The taxa found include also some rare taxa, e.g. Geissleria gereckei CANTONATI et LANGE-BERTALOT (Fig. S1, 24) that occurred with a considerable proportion $(4.5 \%)$, for this rare and never abundant species, in the epilithon of the Veraghi spring. Gomphosphenia holmquistii (Foged) LANGe-Bertalot (Fig. S1-25) is a species rarely recorded in lakes, reservoirs, and their outlets, was found thriving on lithic material in Val di Canova spring, where the outflow (overflow) of the capturing concrete basin was sampled.

After the stepwise model building, the following factors were used into the CCA model: discharge $(\mathrm{F}=$ $3.62, \mathrm{P}=0.001)$, nitrate $(\mathrm{F}=2.05, \mathrm{P}=0.004)$, and impacts $(\mathrm{F}=2.12, \mathrm{P}=0.002)$ (Figs $31-32)$. The model was highly significant $(\mathrm{F}=2.60, \mathrm{P}=0.001)$, and explained $17.4 \%$ of the total variance, whilst the first two axes explained a total of $76.7 \%$ (axis $1=46.8 \%$, axis $2=29.7 \%$ ). The CCA diagrams (Figs 31-32) show that high concentrations of nitrates were found in im-
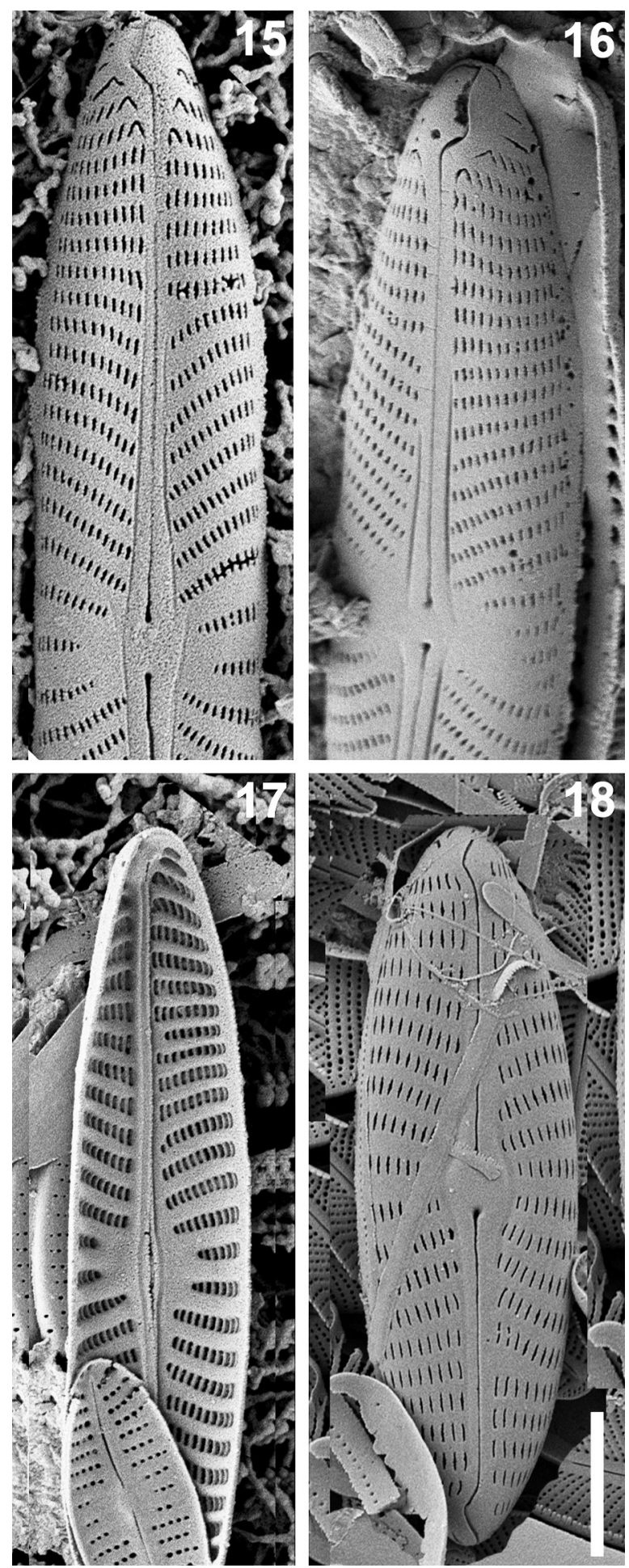

Figs 15-18. (15-17) SEM micrographs of Navicula veronensis sp. nov.; (18) Navicula cincta shown for comparison; $(15-16,18)$ outside view; (17) inside view. Scale bar $3 \mu \mathrm{m}$.

pacted springs, and that e.g., Navicula veronensis sp. nov., Nitzschia frustulum (KützING) GRUNOw in Cleve et GRUNOw preferred such springs. The third important gradient, orthogonal to the first two ones, was discharge. Springs with high discharge were colonized by species like Navicula antonii Lange-Bertalot, Nitzschia fonticola (GRUNOw) GRUNOw in VAN HEURCK and N. lacuum LANGE-BERTALOT. 


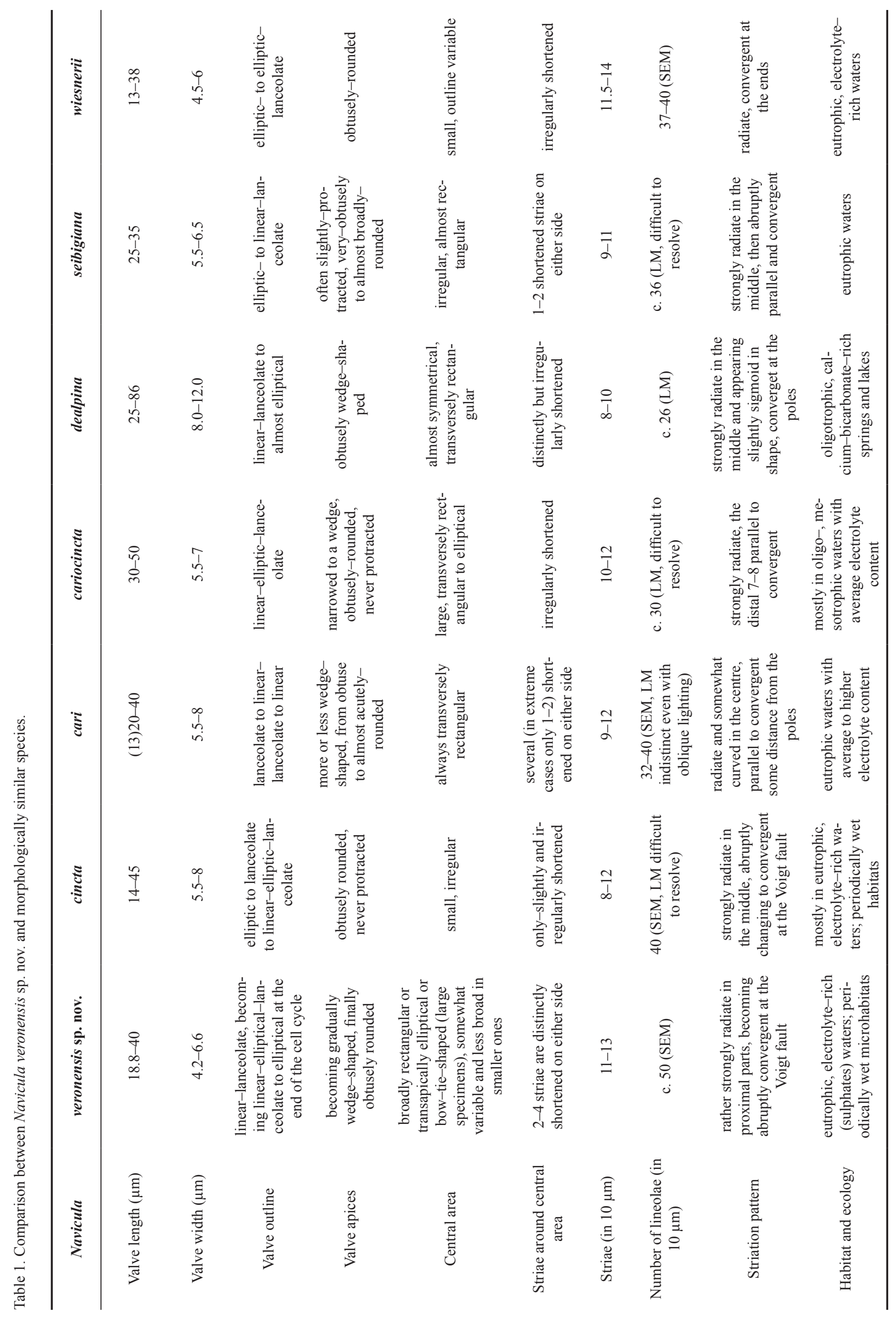



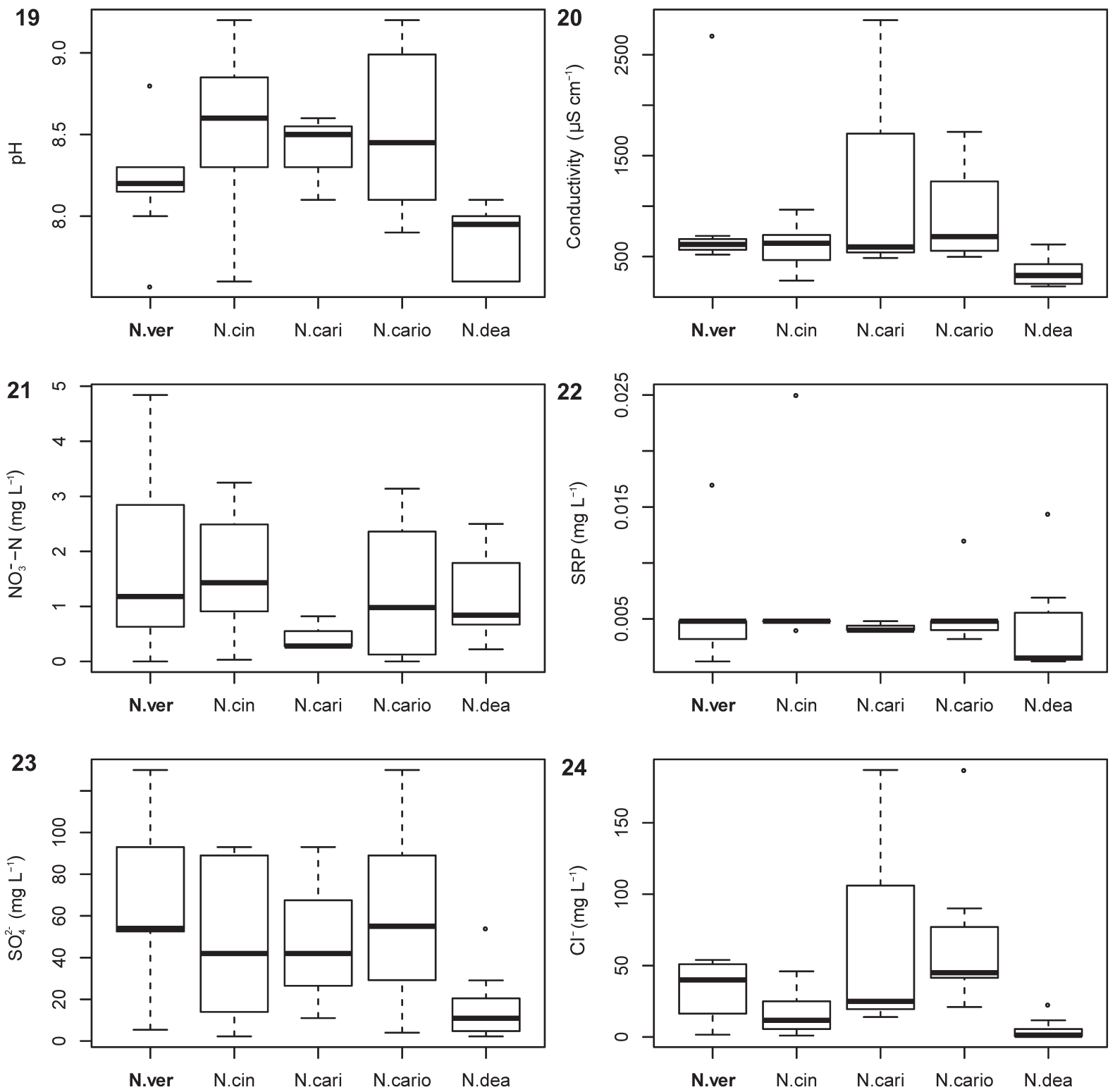

Figs 19-24. Box-and-whisker plots comparing the optima of Navicula veronensis sp. nov. and of allied taxa: (N.ver) Navicula veronensis sp. nov.; (N.cin) Navicula cincta; (N.cari) Navicula cari; (N.cario) Navicula cariocincta, (N.dea) Navicula dealpina.

\section{Discussion}

Although signs of alteration due to human disturbance were evident, several rare taxa were observed, and even a diatom species new to science (Navicula veronensis sp. nov.) was described. The finding of new or rare species is most likely to be due to the high level of detail with which taxonomic studies were conducted (cf. Wojtal 2013).

Three further species, that belong to the group of species around Navicula cincta, were described from central Europe, remarkably all of them from spring habitats. Navicula domiciliensis REICHARDT (2012) was described from a seepage spring in the Opalinuston spring horizon in Treuchtlingen-Bubenheim, Bavaria, Germany. It differs from $N$. veronensis by the smaller, clearly-unilaterally developed, central area, slightly lower stria density (10-11 instead of 11-13 in $10 \mu \mathrm{m})$, and less markedly radiate striae. Navicula fontana ŻELAZNA-WIECZOREK et LANGE-Bertalot nom. prov. is still unpublished but was depicted by ŻELAZNA-WIECZOREK (2011). It was collected in a high-conductivity $\left(400 \mu \mathrm{S} \mathrm{cm}^{-1}\right)$, alkaline spring in Central Poland, and differs from $N$. veronensis by the undifferentiated central area, the smaller width (3.8-4.8 instead of 4.2-6.6 $\mu \mathrm{m})$, and proximal raphe endings shortly deflected to the same side of the valve. Navicula sanctamargaritae Beauger (Beauger et al. 2015), from an inland saline spring, differs by many features, the main ones being the small central area bordered by usually one (rarely 2-3) irregularly shortened striae, the much wider density range of the slightly-curved striae, and the proxi- 
25

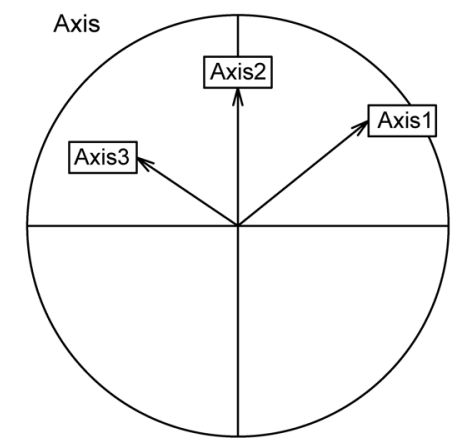

26

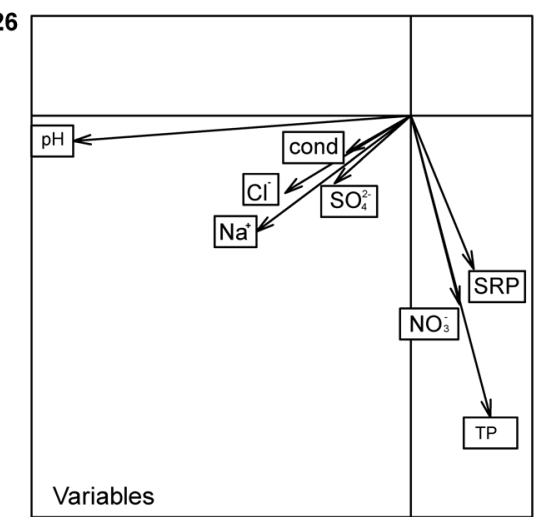

28

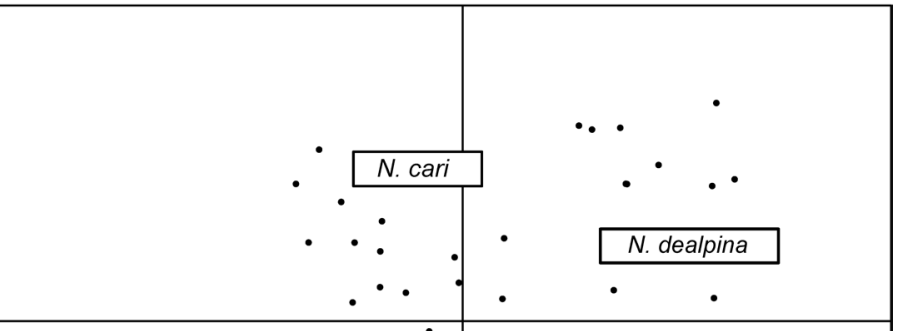

\begin{tabular}{|l|l|}
\hline N. cariocincta & N. veronensis \\
\hline
\end{tabular}

27

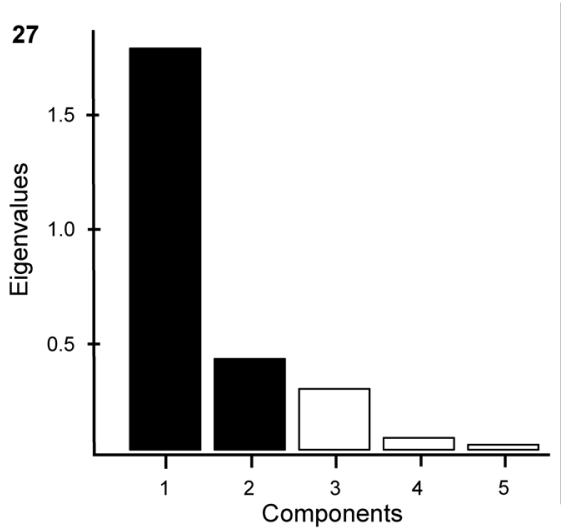

Samples and Species

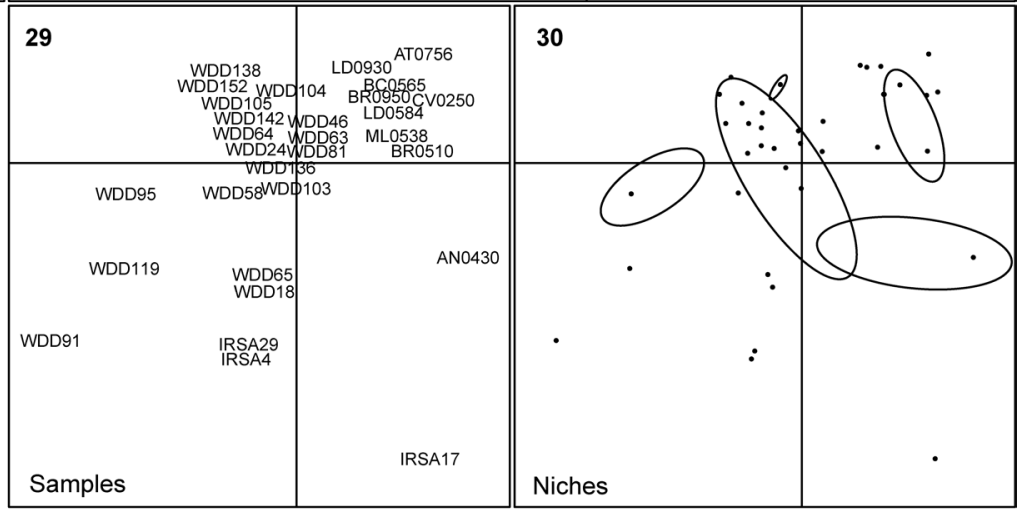

Figs 25-30. Niche parameters of $N$. veronensis sp. nov. and allied species: (25) projection of the first three PCA axes of the environmental variables on the first two axes of the OMI analysis; (26) canonical weights of environmental variables; (27) screen plot of the eigenvalues associated with each component; (28) distribution of the species on the first factorial plane of the OMI analysis. Crosses identify the position of species using the canonical weights of the environmental variables; (29) site labels for Fig. 28; 30. Centers of gravity of the species profiles (weighted average position of the species showed in Fig 28). In Fig. 29 „WDD“ and „IRSA“ samples (sites) are from the Cyprus_diatoms Project, other codes refer to the CRENODAT Project (more details in CANTONATI et al. 2012a).

mal raphe endings clearly deflected towards the secondary side.

Navicula lauca RuMrich et LANGE-BERTALOT was described from a streamlet in the Chilean Andes (RUMrich et al. 2000), and is frequently reported from high-elevation freshwaters of Chile, Bolivia, and Argentina (MAIDANA et al. 2011). It differs from Navicula veronensis sp. nov. by the shape of the endings and of the central area.

$N$. veronensis sp. nov. was shown to be a species with clear preferences for alkaline waters, like the allied species considered in the present study. The restricted range of $\mathrm{pH}$ suitable for its colonization, in- dicated that it might be the most specialized species among those considered. In contrast, nitrate contents were somewhat variable, suggesting that the species can occur in a wide range of situations, though always in unpolluted waters. The niche breadth and niche position of the species revealed that the ecological preferences of $N$. veronensis sp. nov. don't differ substantially from those of the allied species $N$. cincta, $N$. cariocincta, $N$. cari, and N. dealpina.

In general, the composition of diatom assemblages found in the springs studied shows analogies with recent studies on comparable environments (e.g., Żelazna-Wieczorek 2011; Wojtal \& Sobczyk 2012; 

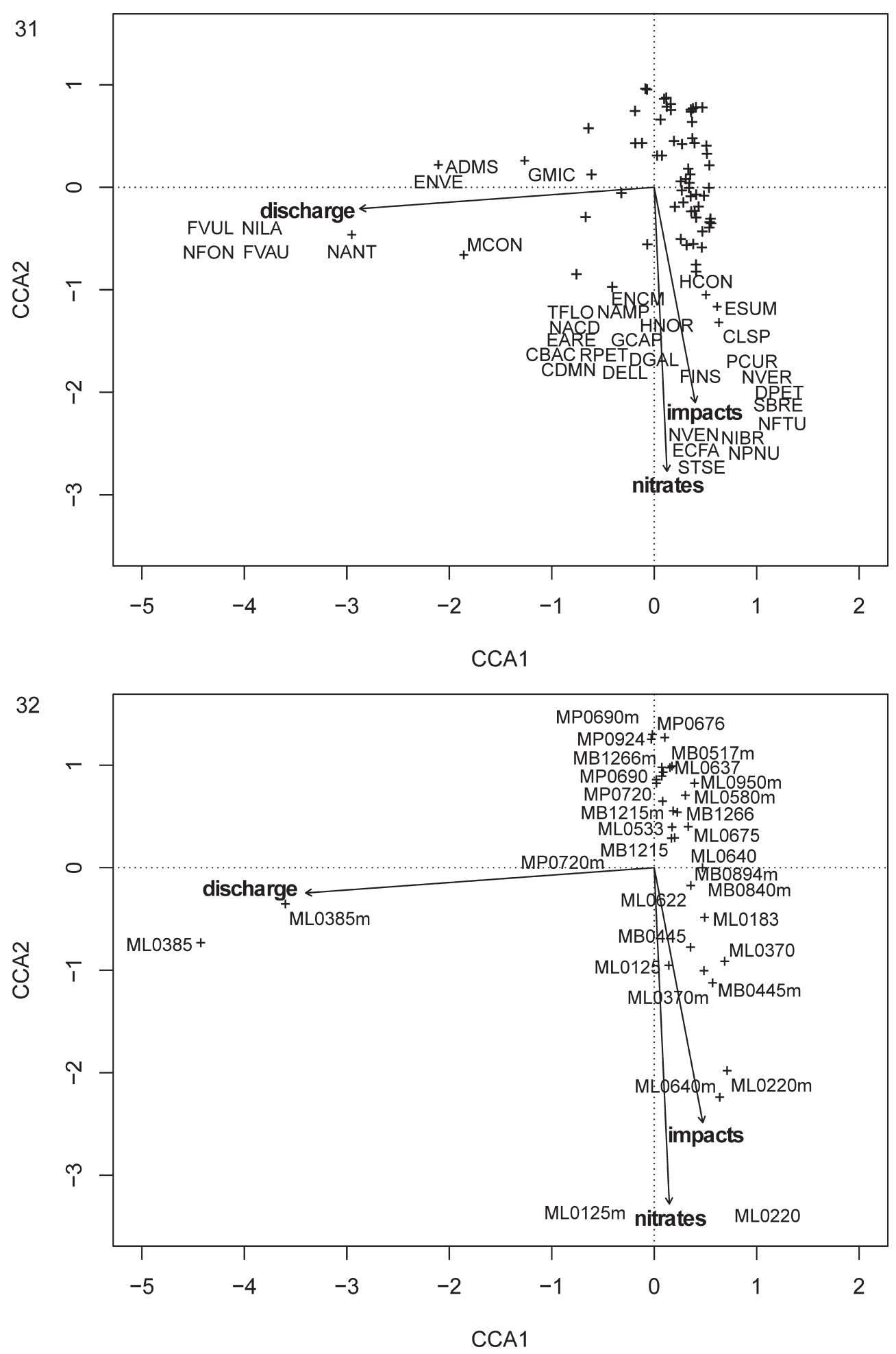

Figs 31-32. CCA ordination diagram with environmental variables represented by arrows. Only species with score $>|1|$ on the CCA axes were showed to avoid labels overlapping in the origin of the biplot. Few site labels were removed when completely overlapped. Species abbreviations (OMNIDIA codes): (ADMS) Adlafia minuscula; (CBAC) Caloneis bacillum; (CDMN) Cymbella diminuta; (CLSP) Caloneis sp.; (DELL) Diploneis elliptica; (DGAL) Diadesmis gallica; (DPET) Diploneis peterseni; (EARE) Ellerbeckia arenaria; (ECFA) Encyonopsis falaisensis; (ENCM) Encyonopsis microcephala; (ENVE) Encyonema ventricosum; (ESUM) Encyonopsis subminuta; (FINS) Fallacia insociabilis; (FVAU) Fragilaria vaucheriae; (FVUL) Frustulia vulgaris; (GCAP) Gomphonema capitatum; (GMIC) Gomphonema micropus; (HCON) Humidophila contenta; (HNOR) Halamphora normannii; (MCON) Meridion constrictum; (NACD) Nitzschia acidoclinata; (NAMP) Nitzschia amphibia; (NANT) Navicula antonii; (NFON) Nitzschia fonticola; (NFTU) Nitzschia frustulum; (NIBR) Nitzschia bryophila; (NILA) Nitzschia lacuum; (NPNU) Nitzschia perminuta; (NVEN) Navicula veneta; (NEVER) Navicula veronensis sp. nov.; (PCUR) Psammothidium curtissimum; (RPET) Rossithidium petersenii; (SBRE) Surirella brebissonii; (STSE) Stauroneis separanda; (TFLO) Tabellaria flocculosa. In the site (sample) codes the number is referred to the elevation of the spring, and the final " $m$ " denotes a bryophyte ("moss") sample (more details in Table 1 in ANGELI et al. 2010). 
Table 2. Results of the niche analysis of Navicula veronesis sp. nov. and allied species [(OMI) Outlying Mean Index, high values means high niche position (species occur in particular habitats); (Tol) tolerance, or niche breadth. Obs and Std.Obs are the observed and the standard deviation of the OMI index under a permuted distribution computed to test the statistical significance of the species marginality (marginality is defined as the ecological distance between the species optimum and the mean habitat within the background data)].

\begin{tabular}{lccccc}
\hline & OMI & Tol & Obs & Std.Obs & $\boldsymbol{P}$ \\
\hline N. veronensis & 0.497 & 0.877 & 0.497 & -0.630 & 0.851 \\
N. cincta & 4.164 & 1.280 & 4.164 & -0.042 & 0.207 \\
N. cari & 2.055 & 0.162 & 2.055 & -0.507 & 0.774 \\
N. cariocincta & 4.506 & 0.667 & 4.506 & -0.157 & 0.267 \\
N. dealpina & 2.824 & 0.065 & 2.824 & 3.213 & $\mathbf{0 . 0 1 4}$ \\
\hline
\end{tabular}

Delgado et al. 2013; Wojtal 2013). The assemblages of the springs studied also show analogies with those of petrifying springs affected by nitrate enrichment (DENYs \& OOSTERLYNCK 2015), which is consistent with the fact that the springs studied included limestone precipitating springs. The most characteristic algae (species involved in biocalcification processes) of LPS appear to be less sensitive to nitrate than to phosphate enrichment (CANTONATI et al. 2016).

These springs, although impacted, still include in their diatom assemblages widely-distributed crenophilous species [e.g., Caloneis fontinalis (GRUNOw) A.Cleve, Cymbella diminuta (Grunow) Reichardt, Odontidium mesodon (Ehrenberg) KützIng, Diploneis fontanella LANGE-Bertalot, D. krammeri LANGE-BERTALOT et REICHARDT, Eunotia arcubus NÖRPELL-SCHEMPP et LANGE-Bertalot, Fragilaria amphicephala (KütZING) Lange-Bertalot, Gomphonema elegantissimum Reichardt et LANGE-BERTAlot, Meridion circulare (Greville) C.Agardh, Rossithidium petersenii (HusTEDT) Round et BuKhtiYarova], mixed with species that are well-known indicators of nutrient enrichment [e.g., Sellaphora nigri (DE Notaris) C.E.Wetzel ET L.ECTOR, Navicula veneta KützING, Nitzschia frustulum, N. inconspicua Grunow)] (cf. CANTONATI 1998; Cantonati \& Spitale 2009).

Besides other anthropogenic pressures (nitrates, artificial morphology of the site of emergence), an important driver is the low discharge, that is likely to cause extensive parts of the substrata to dry out during low flow. Accordingly, applying the moisture index of VAN DAM et al. (1994), 24.6\% of the taxa were found to belong to categories $4+5$, i.e. those including species occurring in temporarily dry places or outside water bodies. The large majority of the taxa $(50.8 \%)$ were in category 3 , i.e. taxa occurring in water bodies but regularly found also found in damp places (ANGELI et al. 2010). Examples of well-known pseudaerial / euaerial species found in the springs studied are: Adlafia minuscula var. muralis (GRUNOW) LANGE-BERTALOT, Diadesmis gallica W.Smith, Eunotia arcubus, Humi- dophila aerophila (KRASSKE) Lowe et al., H. contenta (Grunow) Lowe et al., H. paracontenta (LANGE-BerTAlot \& Werum) Lowe et al., $H$. perpusilla (Grunow) Lowe et al., Luticola nivalis (EHRENBERG) D.G. MANN. To this regard, also the finding of Geissleria gereckei, a species described from carbonate springs with extremely low discharge, is significant, in particular in the light of a recent work (VIDAKOVIĆ et al. 2016) that showed that this species can colonize also environments affected by nutrient enrichment, and that the most determinant driver of its distribution is stronglyfluctuating discharge causing the desiccation of large parts of the substrata within the wetted perimeter of springs and streams.

\section{ACKnowledgements}

Data used for the present paper were gained from the following projects: CESSPA (Census and Study of Springs and Wells of the Adige River Basin, 2008-2009; Adige River Basin Authority \& Natural History Museum of Verona), CRENODAT (Biodiversity assessment and integrity evaluation of springs of Trentino - Italian Alps - and long-term ecological research, 2004-2008; University and Scientific Research Department of the Autonomous Province of Trento). Cyprus_diatoms (Diatoms of the running waters of Cyprus, 20122013; Government of Cyprus - Water Development Department \& Prothea S.r.l., Milan, Italy). We thank Gerald Dörflinger, Water Development Dept. (Division of Hydrometry), Republic of Cyprus, and David Armanini, Prothea Srl, for making available morphological, physical, and chemical data on the Cypriot streams. We are grateful to Regine Jahn, Senior Curator, Algae Herbarium Botanischer Garten und Botanisches Museum Berlin-Dahlem, and to Jana Veselá, Collection Manager, Diatom Herbarium, Academy of Natural Sciences of Drexel University of Philadelphia (PA, USA), for quick assignment of isotype materials' codes and for useful comments on the deposition of materials and data.

\section{REFERENCES}

Aboal, M.; Puig, M. \& Prefasi, M. (1998): Diatom assemblages in springs in Castellón province (Eastern Spain). - Algological Studies 90: 79-95.

Angeli, N.; Cantonati, M.; Spitale, D. \& Lange-Bertalot, H. (2010): A comparison between diatom assemblages in two groups of carbonate, low-altitude springs with different levels of anthropogenic disturbances. - Fottea 10: 115-128.

Beauger, A.; Voldoire, O.; Mertens, A.; Le Cohu, R. \& Van De ViJver, B. (2015): Two new Navicula species (Bacillariophyceae) from Western Europe. - Phytotaxa 230: $172-182$.

Bertrand, J.; Renon, J.-P. \& Monnier, O. (1999): Les diatomées des sources du rebord karstique de la Beauce de la région orléanaise. - Symbioses 1: 3-14.

Cantonati, M. (1998): Diatom communities of springs in the Southern Alps. - Diatom Research 13: 201-220.

Cantonati, M. \& Lange-Bertalot, H. (2009): Geissleria gereckei sp. nov. (Bacillariophyta) from leaf-litter covered stones of very shaded carbonate mountain springs with extremely low discharge. - Phycological Research 57: 171-177.

Cantonati, M. \& Spitale, D. (2009): The role of environmental variables in structuring epiphytic and epilithic diatom assemblages in springs and streams of 
the Dolomiti Bellunesi National Park (south-eastern Alps). - Fundamental and Applied Limnology 174: 117-133.

Cantonati, M.; Angeli, N.; Bertuzzi, E.; Spitale, D. \& Lange-Bertalot, H. (2012a). Diatoms in springs of the Alps: spring types, environmental determinants, and substratum. - Freshwater Science 31: 499-524.

Cantonati, M.; Füreder, L.; Gerecke, R.; Jüttner, I. \& Cox, E.J. (2012b): Crenic habitats, hotspots for freshwater biodiversity conservation: toward an understanding of their ecology. - Freshwater Science 31: 463-480.

Cantonati, M.; Kelly, M.G.; Armanini, D.; Lange-Bertalot, H.; Angeli, N.; Demartini, D. \& Dörflinger, G. (2015): Diatom biodiversity in Mediterranean streams and its potential for environmental assessments: a case study from the Island of Cyprus. Society for Freshwater Science (SFS) 2015 Annual Meeting, Milwaukee, Wisconsin, USA, May 16-23, 2012.

Cantonati, M.; Segadelli, S.; Tran, H.; Ogata, K.; Gerecke, R.; Sanders, D.; Rott, E.; Gargini, A.; Celico, F. \& FilippinI, M. (2016): Petrifying Springs: A global review on ambient Limestone-Precipitating Springs (LPS): Hydrogeological setting, ecology and conservation. - The Science of the Total Environment. http://dx.doi.org/10.1016/j.scitotenv.2016.02.105

Delgado, C.; Ector, L.; Novais, M.H.; Blanco, S.; HoffMANN, L. \& PARDO, I. (2013): Epilithic diatoms of springs and springs-fed streams in Majorca Island (Spain) with the description of a new diatom species Cymbopleura margalefii sp. nov. - Fottea 13: 87-104.

Denys, L. \& Oosterlynck, P. (2015): Diatom assemblages of non-living substrates in petrifying Cratoneurion springs from lower Belgium. - Fottea, 15:123-138.

Dolédec, S.; Chessel, D. \& Gimaret, C. (2000): Niche separation in community analysis: a new method. Ecology 81: 2914-1927.

EU-HD (Habitat Directive) (1992): Council Directive 92/43/ EEC of 21 May 1992 on the Conservation of natural habitats and of wild fauna and flora (EC Habitats Directive). - Official Journal of the European Communities L 206: 7-50.

Hofmann, G.; Werum, M. \& Lange-Bertalot, H. (2011): Diatomeen im Süßwasser-Benthos von Mitteleuropa. Bestimmungsflora Kieselalgen für die ökologische Praxis. Über 700 der häufigsten Arten und ihre Ökologie. A.R.G. Gantner Verlag.

Jüttner, I.; Williams, D.M.; Levkov, Z.; Falasco, E.; Battegazzore, M.; Cantonati, M.; Van de Vijver, B.; Angele, C. \& Ector, L. (2015): Reinvestigation of the type material for Odontidium hyemale (Roth) Kützing and related species, with description of four new species in the genus Odontidium (Fragilariaceae, Bacillariophyta). - Phytotaxa 234: 1-36. DOI 10.11646/phytotaxa.234.1.1

Krammer, K. (1997a): Die cymbelloiden Diatomeen. Teil 1. Allgemeines und Encyonema Part. - Bibliotheca Diatomologica 36: 1-382.

Krammer, K. (1997b): Die cymbelloiden Diatomeen. Teil 2. Encyonema part., Encyonopsis and Cymbellopsis. Bibliotheca Diatomologica 37: 1-469.

Krammer, K. \& Lange-Bertalot, H. (1986-1991): Bacillariophyceae. Naviculaceae, Vol. 2/1, 876 pp.; Bacillariaceae, Epithemiaceae, Surirellaceae, Vol. 2/2, 596 pp.; Centrales, Fragilariaceae, Eunotiaceae, Vol.
2/3, 576 pp.; Achnanthaceae, Vol. 2/4, 437 pp. - In: Ettl, H.; Gerloff, J.; Heynig, H. \& Mollenhauer, D. (eds): Sűßwasserflora von Mitteleuropa. - G. Fisher, Stuttgart. New York.

Krammer, K. (2002-2003): Cymbella, Vol. 3, 584 pp.; Cymbopleura, Delicata, Navicymbula, Gomphocymbellopsis, Afrocymbella, Vol. 4, 530 pp. - In: LANGE Bertalot, H. (ed.): Diatoms of Europe. - A.R.G. Gantner Verlag K.G, Ruggell.

Krammer, K. \& Lange-Bertalot, H. (2004): Bacillariophyceae. Achnanthaceae. - In: Ettl, H.; Gärtner, G.; Heynig, H. \& Mollenhauer, D. (eds): Süßwasserflora von Mitteleuropea, Vol. 2/4. - 468 pp., G. Fisher, Stuttgart. New York.

Lange-Bertalot, H. (2001): Navicula sensu stricto, 10 Genera separated from Navicula sensu lato, Frustulia. In Lange-Bertalot, H. (Ed.) Diatoms of Europe, 2: 1-526. A.R.G. Gantner Verlag, K.G., Ruggell.

Lecointe, C.; Coste, M. \& Prygiel, J. (1993): OMNIDiA: software for taxonomy, calculation of diatom indices and inventories management. - Hydrobiologia 269/270: 509-513.

LeVkov, Z. (2009): Amphora sensu lato. - In: LANGE-BERTALOT, H. (ed.): Diatoms of Europe: Diatoms of the European Inland Waters and Comparable Habitats, Vol. 5. - pp. 5-916, A.R.G. Gantner Verlag K.G., Ruggell.

Liu, Y.; Kociolek, J.P.; Fan, Y. \& Wang, Q. (2012): Pseudofallacia gen. nov., a new freshwater diatom (Bacillariophyceae) genus based on Navicula occulta Krasske. - Phycologia 51: 620-626.

Lowe, R.L.; Kociolek, J.P.; Johansen, J.R.; Van De ViJver, B.; Lange-Bertalot, H. \& Kopalová, K. (2014): Humidophila gen. nov., a new genus for a group of diatoms (Bacillariophyta) formerly within the genus Diadesmis: species from Hawai'i, including one new species. - Diatom Research 29: 351-360.

Maidana, N.I.; Seeligmann, C.; Marcelo, Y. \& Morales, R. (2011): El género Navicula sensu stricto (Bacillariophyceae) en humedales de altura de Jujuy, Argentina. - Bol. Soc. Argent. Bot. 46: 13-29.

R Core TEAm (2015): R: A language and environment for statistical computing. R Foundation for Statistical Computing, Vienna, Austria. URL http://www.R-project. org/.

ReIchardt, E. (1997): Taxonomische Revision des Artenkomplexes um Gomphonema pumilum (Bacillariophyceae). - Nova Hedwigia 65: 99-129.

ReIchardt, E. (2012): Neue Diatomeen (Bacillariophyceae) aus dem Gebiet der Stadt Treuchtlingen. - Berichte der Bayerischen Botanischen Gesellschaft 82: 19-32.

Round, F.E.; Crawford, R.M. \& Mann, D.G. (1990): The diatoms, biology and morphology of the genera. -747 pp., Cambridge University Press, Cambridge.

Rumrich, U.; Lange-Bertalot, H. \& Rumrich, M. (2000): Diatomeen der Anden. - Iconographia Diatomologica 9: 1-673.

Spitale, D.; Leira, M.; Angeli, N. \& Cantonati, M. (2012): Environmental classification of springs of the Italian Alps and its consistency across multiple taxonomic groups. - Freshwater Science 31: 563-574.

TAXвÖCK, L. \& PreIsIG, H.R. (2007): The diatom communities in Swiss springs: A first approach. - In: KUSBER, W.-H. \& JAHN, R. (eds): Proceedings of the 1st Central European Diatom Meeting. - pp. 163-168, Botanic Garden and Botanical Museum Berlin-Dahlem, 
Freie Universität Berlin. ISBN 978-3-921800-63-8, doi:10.3372/cediatom.134.

Tsarenko, P.M.; Lange-Bertalot, H.; Stupina, V.V. \& WasSER, S.P. (2000): Bacillariophyta. -In: Nevo, E. \& WASSER, S.P. (eds): Biodiversity of cyanoprokaryotes, algae and fungi of Israel. Cyanoprokaryotes and algae of continental Israel. - pp. 195-335, A.R.A. Gantner Verlag K.G., Ruggell.

Vidaković, D.; Cantonati, M.; Mogna, M.; Jakovljević, O.; Šovran, S.; Lazović, V.; Stojanović, K.; ĐorĐević, J. \& Krizmanić, J. (2016): Improving knowledge on the distribution and ecology of the recently described diatom species Geissleria gereckei. - Oceanological and Hydrobiological Studies, Submitted.

Van Dam, H.; Mertens, A. \& SinKeldam, J. (1994): A coded checklist and ecological indicator values of freshwater diatoms from the Netherlands. - Netherlands Journal of Aquatic Ecology 28: 117-133.

Werum, M. \& Lange-Bertalot, H. (2004): Diatoms in
Springs from Central Europe and elsewhere under the influence of hydrogeology and anthropogenic impacts. - In: LANGe-BerTalot, H. (ed.): Iconographia Diatomologica, Vol. 13. - pp. 1-417, Koeltz, Koenigstein.

Wojtal, A.Z. (2013): Species composition and distribution of diatom assemblages in spring waters from various geological formations in southern Poland. - Bibliotheca Diatomologica 59: 1-436.

Wojtal, A.Z. \& Sobczyк, Ł. (2012): The influence of substrates and physicochemical factors on the composition of diatom assemblages in karst springs and their applicability in water-quality assessment. - Hydrobiologia 695: 97-108.

ŻelaznA-WieCZOREK, J. (2011): Diatom flora in springs of Lódz Hills (Central Poland). Biodiversity, taxonomy and temporal changes of epipsammic diatom assemblages in springs affected by human impact. - 419 pp., A.R.G. Gantner Verlag K.G., Ruggell.

Supplementary material

the following supplementary material is available for this article:

Fig. S1. LM micrographs of the 30 most abundant species.

Table 1. Diatom taxa list (all substrata) with frequency and maximum relative abundance.

This material is available as part of the online article (http://fottea.czechphycology.cz/contents)

(C) Czech Phycological Society (2016)

Received January 17, 2016

Accepted April 18, 2016 